\title{
Ontogeny of Growth Hormone Releasing Hormone and Insulin-Like Growth Factors-I and -II Messenger RNA in Rat Placenta ${ }^{1}$
}

\author{
ORA HIRSCH PESCOVITZ, NANCY B. JOHNSON, AND SUSAN A. BERRY
}

Departments of Pediatrics [O.H.P., N.B.J.] and Physiology and Biophysics [O.H.P.], Indiana University Medical Center, Indianapolis, Indiana 46223 and Department of Pediatrics, University of Minnesota, Minneapolis, Minnesota 55455 [S.A.B.]

\begin{abstract}
Hypothalamic growth hormone releasing hormone (GHRH) stimulates pituitary growth hormone secretion, which is essential for normal postnatal growth. Reports of an immunoreactive and biologically active GHRH-like peptide in placenta led us to investigate placental expression of GHRH mRNA. Placentas from d 19 gestation fetal rats were assayed for GHRH-like peptide by ELISA and for GHRH mRNA. Placenta GHRH-like peptide levels averaged $3.7 \pm 0.2 \mathrm{ng} / \mathrm{g}$ tissue. Dot-blot hybridization revealed the presence of GHRH mRNA in rat placenta in quantities greater than those of the message in rat hypothalamus. Northern gel analysis of poly-A enriched RNA was used to evaluate the specificity of GHRH mRNA hybridization and to determine the size of the placental mRNA. Placental and hypothalamic GHRH mRNA were of nearly identical size, although placental RNA had a broad band of hybridization that extended below that seen in hypothalamus. Further confirmation of homology between placental and hypothalamic GHRH mRNA was determined by an RNAse protection assay, in which a placental protected fragment was identical in size to that resulting from protection of the hypothalamic complementary RNA. The ontogeny of GHRH mRNA in rat placenta was determined by dot-blot hybridization. The message was detected at the earliest date examined, d 7 , and increased more than 2-fold by $\mathbf{d} \mathbf{1 4}$ and 5-fold by $\mathrm{d} 17$. The ontogeny of IGF-I and IGF-II mRNA in placenta was also determined. IGF-I mRNA was detected at all gestational dates examined, but was highest on $\mathrm{d} 10$, whereas IGF-II mRNA was not detectable on $d 7$ or 10 but was present on $d 14,17$, and 20 . We conclude that GHRH mRNA is present in rat placenta at least from d 7 of gestation. Placental expression of GHRH mRNA is concurrent with maximal expression of placental IGF-II, but not IGF-I mRNA. The similar time course of expression for GHRH mRNA and IGF-II leads us to speculate that they may have related functions in the last week of rat gestation. (Pediatr Res 29: 510-516, 1991)
\end{abstract}

\section{Abbreviations}

GHRH, growth hormone releasing hormone cRNA, complementary RNA

Received June 1, 1990; accepted December 20, 1990

Correspondence and reprint requests: Ora Hirsch Pescovitz, M.D., Associate Professor of Pediatrics, Physiology/Biophysics, Riley Hospital for Children A593, Indiana University Medical Center, 702 Barnhill Drive, Indianapolis, IN 46223.

Supported by Biomedical Research Grant PHS SO7 RR 5371J, NIH Grant R01DK 41899, Riley Memorial Association, the Minnesota Medical Foundation, the Variety Club, and Viking's Children Fund.

Presented in part at the 70th Annual Endocrine Society Meeting, New Orleans, June 1988

\author{
TFA, trifluoroacetic acid \\ tRNA, transfer RNA \\ PLP, prolactin-like protein \\ PL, placental lactogen \\ GH, growth hormone \\ UTP, uridine triphosphate
}

The placenta is a rich source of hypothalamic neuropeptides including corticotrophin releasing hormone (1), gonadotropin releasing hormone (2), thyrotropin releasing hormone (3), and proopiomelanocortin (4). Two reports have also documented the presence of immunoreactive $(5,6)$ and biologically active GHRH in rat placenta. Because the placenta has mechanisms for concentrating circulating substances for subsequent delivery to the fetus, these findings are only inferential proof of a placental origin for GHRH. GHRH mRNA has also recently been reported in placenta (7-9). We now confirm the presence of immunoreactive GHRH and GHRH mRNA in rat placenta. To begin to explore a physiologic role for GHRH in utero, we examined the ontogeny of GHRH mRNA in rat placenta. To determine if GHRH expression correlates with that of other growth factors, the ontogeny of IGF-I and IGF-II mRNA in placenta was also studied.

\section{MATERIALS AND METHODS}

Antiserum generation. Antibodies were generated in New Zealand White rabbits as previously described (10). After the booster, the animals were bled weekly and the serum assayed in modifications of a previously described ELISA for the detection of antiGHRH antibodies $(11,12)$.

Animals Animals were maintained in accordance with the NIH Guide for the Care and Use of Laboratory Animals. Timedpregnant Sprague-Dawley rats were obtained from Taconic Farms (Germantown, NY). Eight timed-pregnant rats were studied for determination of the ontogeny of placental mRNA. Two pregnant rats from each of the following days of gestation yielded placentas for study: d 7 (31 fetuses/placentas); d 10 (22 fetuses/ placentas); and d 14 (30 placentas). One pregnant rat yielded 12 placentas at $d 17$ of gestation and one rat yielded 12 placentas at d 20 of gestation. On gestational d 7 and 10, we did not achieve complete separation of the fetus from the placenta.

Tissue extraction and GHRH ELISA. Placentas were extracted for GHRH ELISA using modifications of previously described methodology $(6,13)$. In brief, they were homogenized with icecold $50 \%$ acidified methanol $\left(0.1 \mathrm{~N} \mathrm{HCl}-\mathrm{CH}_{3} \mathrm{OH}\right)$ with the addition of phenyl-methylsulfonylfluoride $(10 \mu \mathrm{g} / \mathrm{mL})$ and pepstatin $(10 \mu \mathrm{g} / \mathrm{mL})$. The homogenate was spun at $48000 \times \mathrm{g}$ for 
$30 \mathrm{~min}$ at $4^{\circ} \mathrm{C}$. The supernatant was further extracted over a C18 Sep-pak cartridge (Waters Associates, Milford, MA) that had been treated by successive 4-mL washes of $0.01 \mathrm{M}$ TFA, $80 \%$ acetonitrile $/ 20 \% 0.01 \mathrm{M}$ TFA ( $\mathrm{vol} / \mathrm{vol}$ ), and $0.01 \mathrm{M} \mathrm{TFA}$. Acidified samples were applied to the cartridge and eluted with $80 \%$ acetonitrile $/ 20 \% 0.01 \mathrm{M}$ TFA. The extract was dried and reconstituted in $1 \mathrm{~mL}$ PBS buffer. After a 15 -min incubation at $37^{\circ} \mathrm{C}$, samples were centrifuged at $1500 \times g$ for $10 \mathrm{~min}$ and the supernatant assayed for GHRH. A direct-binding rat GHRH ELISA was used to measure GHRH immunoreactivity in placenta. Details of this assay have previously been described (10).

RNA extraction. Extraction of total RNA from placenta and hypothalamus was by guanidine- $\mathrm{HCl}$ (14). Aliquots of tissue (100 mg) were homogenized in 10 volumes of $7 \mathrm{M}$ guanidine$\mathrm{HCl}, \mathrm{pH} 5.5,20 \mathrm{mM}$ sodium acetate, $240 \mathrm{mM}$ ammonium acetate, $1 \mathrm{mM}$ DTT, $10 \mathrm{mM}$ iodoacetate. Homogenates were adjusted to $0.5 \%$ sodium sarcosyl and centrifuged, and the supernatant precipitated at $-20^{\circ} \mathrm{C}$ for $48 \mathrm{~h}$ with $1 / 2$ volume of ethanol. Precipitates were dissolved in $7 \mathrm{M}$ guanidine- $\mathrm{HCl}, \mathrm{pH}$ 7.0, $20 \mathrm{mM}$ sodium acetate, $1 \mathrm{mM}$ DTT, $20 \mathrm{mM}$ sodium EDTA, $10 \mathrm{mM}$ iodoacetate and precipitated with $1 / 20$ volume $2 \mathrm{M}$ sodium acetate, $\mathrm{pH} 5.0$, and $1 / 2$ volume of ethanol. These RNA pellets were dissolved and precipitated two additional times, then washed with ethanol:0.1 $\mathrm{M}$ sodium acetate, $\mathrm{pH} 5.0$ (2:1), and dissolved in $10 \mathrm{mM}$ Tris $\mathrm{HCl}, 0.1 \mathrm{mM}$ EDTA, pH 7.6. The dissolved RNA was extracted three times with chloroform:isoamyl alcohol (24:1) and precipitated. Poly-A enriched RNA were obtained by one cycle of oligo-(dT) cellulose. One mg of total RNA from placenta (extracted from $\sim 400 \mathrm{mg}$ of placental tissue fragmented from a single $0.5-\mathrm{g}, \mathrm{d} 20$ gestation placenta) and $800 \mu \mathrm{g}$ of total RNA obtained from extraction of 16 pooled hypothalami (yielded $925 \mu \mathrm{g}$ of total RNA) were chromatographed, yielding 33 and $38 \mu \mathrm{g}$ of poly-A enriched RNA, respectively.

Preparation of $c R N A$ for hybridization. Rat hypothalamic GHRH cDNA (gift of Ron Evans, Salk Institute, San Diego, CA) and IGF-I and IGF-II CDNA $(15,16)$ were subcloned into plasmid vector pSP-72 (Promega, Madison, WI). RNA was generated using either T7- or SP6-RNA polymerases. Polymerase reactions were performed in $40 \mathrm{mM}$ Tris- $\mathrm{HCl}, \mathrm{pH} 8.0,5 \mathrm{mM}$ DTT with $1 \mathrm{mM}$ ATP, cytidine triphosphate, and guanosine triphosphate, in the presence of $1 \mathrm{U} / \mu \mathrm{L}$ of RNA polymerase for $30 \mathrm{~min}$ at $37^{\circ} \mathrm{C}(17)$. Cold sense-strand RNA was prepared for GHRH, IGF-I, and IGF-II standards and for demonstration of GHRH RNAse protection by addition of $1 \mathrm{mM}$ cold UTP only. Antisense-[ $\left.{ }^{32} \mathrm{P}\right]$-labeled RNA was prepared as a probe for GHRH hybridizations by addition of $40 \mu \mathrm{M}$ UTP and $50 \mu \mathrm{Ci}\left[{ }^{32} \mathrm{P}\right]-\mathrm{UTP}$. $\mathrm{Sp}$ act of labeled probes was 1 to $8 \times 10^{8} \mathrm{cpm} / \mu \mathrm{g}$ cDNA.

Preparation of IGF-I and IGF-II CDNA for hybridization. For hybridization of IGF-I and IGF-II cDNA to placental total RNA, IGF-I (14) and IGF-II (gift of Matthew Rechler, NIH, Bethesda, MD) (16) cDNA were used. The cDNA were excised by digestion with the appropriate restriction endonucleases and labeled by random primer extension $(18,19)$ with $50 \mu \mathrm{Ci}\left[{ }^{32} \mathrm{P}\right]$-deoxycytidine triphosphate using a kit from Pharmacia Inc. (Piscataway, $\mathrm{NJ})$. Sp act of probes ranged from 7 to $10 \times 10^{8} \mathrm{cpm} / \mu \mathrm{g} \mathrm{cDNA}$

Preparation of RNA for hybridization. Dot blots were prepared as previously described using concentrations of $4,2,1$, and 0.5 $\mu \mathrm{g}$ of total RNA (14). For standards, $0.5-32 \mathrm{pg}$ of cold sense strand GHRH, 4-96 pg IGF-I cRNA, or 2.5-100 pg IGF-II cRNA were also applied to dot blots. To control for nonspecific hybridization, equal quantities of yeast tRNA were placed on each filter. For comparison of hypothalamic and placental GHRH mRNA, $10 \mu \mathrm{g}$ of placenta and hypothalamic poly-A RNA were electrophoresed in a $1.8 \%$ agarose gel in $2.2 \mathrm{M}$ formaldehyde- $20 \mathrm{mM}$ phosphate. For Northern blots of the ontogeny studies, $10 \mu \mathrm{g}$ of total RNA from representative samples at each gestation date were electrophoresed in a $1.5 \%$ agarose gel. Sample buffers included ethidium bromide to facilitate visualization of ribosomal RNA bands, evaluate transfer of the samples, ensure the absence of degradation, and assess the relative quantities applied. The RNA was transferred to Zetaprobe membrane (Bio-Rad Laboratories, Richmond, CA) by electrotransfer in $7.5 \mathrm{mM}$ Tris, $\mathrm{pH} 7.8,3.75 \mathrm{mM}$ sodium acetate, 37.5 $\mu \mathrm{M}$ EDTA at $80 \mathrm{~V}$ for $6 \mathrm{~h}$.

Hybridization and washing. Blots used in RNA-RNA hybridizations (GHRH) were prehybridized and hybridized in $50 \%$ formamide, $2.5 \times$ Denhardt's solution, $50 \mathrm{mM}$ sodium phosphate, $\mathrm{pH} 7.5,1 \mathrm{mM}$ EDTA, $0.8 \mathrm{M} \mathrm{NaCl}, 10 \mu \mathrm{g} / \mathrm{mL}$ poly-A, $200 \mu \mathrm{g} / \mathrm{mL}$ sheared salmon sperm DNA, $100 \mu \mathrm{g} / \mathrm{mL}$ yeast tRNA. Northern blots were prehybridized in $50 \%$ formamide, $5 \times$ Denhardt's solution, $0.5 \%$ SDS, $5 \times$ SSPE $(1 \times$ SSPE is $180 \mathrm{mM}$ $\mathrm{NaCl}, 10 \mathrm{mM}$ sodium phosphate, pH 7.5, 1 mM EDTA), 200 $\mu \mathrm{g} / \mathrm{mL}$ sheared salmon sperm DNA. Hybridization solution was the same, except the concentration of Denhardt's solution was decreased to $2.5 \times$. Prehybridization was for 4- $12 \mathrm{~h}$ and hybridization was for $18-24 \mathrm{~h}$ at $60^{\circ} \mathrm{C}$. Filters were washed in $1 \times$ SSPE, $0.1 \%$ SDS for $15 \mathrm{~min}$ at room temperature, three times in $1 \times$ SSPE, $0.1 \%$ SDS at $65^{\circ} \mathrm{C}$ for 20 min each, and in $0.1 \times$ SSPE, $0.1 \%$ SDS at $60^{\circ} \mathrm{C}$ for $50 \mathrm{~min}$.

For RNA-DNA hybridizations (IGF-I, IGF-II), prehybridization and hybridization were carried out in $50 \%$ formamide, $5 \times$ Denhardt's solution, $50 \mathrm{mM}$ sodium phosphate, $\mathrm{pH} 7.5,0.2 \%$ SDS, $200 \mu \mathrm{g} / \mathrm{mL}$ sheared salmon sperm DNA, $100 \mu \mathrm{g} / \mathrm{mL}$ yeast tRNA. Times of prehybridization and hybridization were as for RNA-RNA hybrids, but were at $42^{\circ} \mathrm{C}$. Filters were washed for 10 min at room temperature in $2 \times \mathrm{SSC}, 0.1 \%$ SDS four times, and in $0.2 \times \mathrm{SSC}, 0.2 \% \mathrm{SDS}$ at $60^{\circ} \mathrm{C}$ two to three times. All filters were exposed to Kodak XAR-5 film (Eastman Kodak, Rochester, NY) for times varying from $12 \mathrm{~h}$ to $10 \mathrm{~d}$.

$R N A$ se protection assay. Aliquots of in vitro generated GHRH $(10-100 \mathrm{pg})$ or placental RNA $(25 \mu \mathrm{g})$ were hybridized in solution to antisense- $\left.{ }^{32} \mathrm{P}\right]$-labeled GHRH RNA (20). Hybridizations were performed at $80^{\circ} \mathrm{C}$ in $10 \mathrm{mM}$ Tris- $\mathrm{HCl}, \mathrm{pH} 7.5,0.3 \mathrm{M} \mathrm{NaCl}, 2$ mM EDTA, $20 \%$ formamide for 16-18 h. After hybridization, the hybrids were treated with RNAses A and T1, followed by proteinase $\mathrm{K}$ digestion and extraction with phenol-chloroform. Samples were precipitated and applied to an $8 \%$ acrylamide, 8 $\mathrm{M}$ urea gel in $89 \mathrm{mM}$ Tris, $89 \mathrm{mM}$ borate, $2 \mathrm{mM}$ EDTA and subjected to electrophoresis at $110 \mathrm{~V}$ for $3 \mathrm{~h}$. The gel was dried and exposed to Kodak XAR-5 film for $24 \mathrm{~h}$.

Data analysis. The data are expressed as the mean \pm SEM. The significance of changes during gestation was determined using analysis of variance (Statview 512+; Brainpower, Inc., Calabasa, CA). Dot blots were quantitated by videodensitometry using a modification of the method of Mariash et al. (21). Imaging was performed with a JVC model GX-N8U color videocamera with the program "Quick Capture" and a Macintosh II computer.

\section{RESULTS}

Immunoreactive GHRH in placenta. GHRH immunoreactivity in rat placenta was confirmed in the ELISA. GHRH concentrations averaged $3.7 \pm 0.2 \mathrm{ng} / \mathrm{g}$ of wet weight $(n=5 ; 0.1 \mathrm{~g}$ tissue/initial well) from gestational d 20 placentas. No GHRH was detected in any plasma samples. GHRH content of hypothalami from 60 -d-old male rats served as a positive control and averaged $0.32 \mathrm{ng} \mathrm{GHRH} /$ hypothalamus. Recovery of exogenous GHRH after extraction averaged $80 \%$. The least detectable dose was $40 \mathrm{pg}$ per well. The intraassay and interassay coefficients of variation at the $\mathrm{ED}_{50}$ were 8.3 and $14.9 \%$, respectively.

GHRH $m R N A$ in placenta. Dot-blot hybridization of placental total RNA resulted in a hybridization signal that was more intense than that generated by hybridization to total hypothalamic RNA (Fig. 1). Because the distribution of GHRH in hypothalamus is limited to a small region, comparison of amounts of RNA may be affected significantly by the size of the tissue block used for extraction. The more intense signal in placenta suggests that GHRH in placenta is more generally distributed 


\section{$\begin{array}{lllll}0.5 & 1 & 2 & 4 & \mu \mathrm{g}\end{array}$}

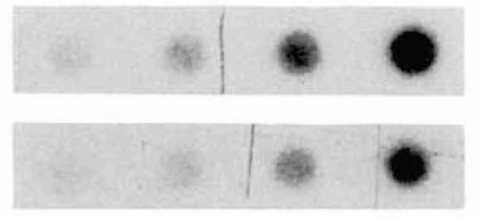

\section{Placenta}

Hypothalamus

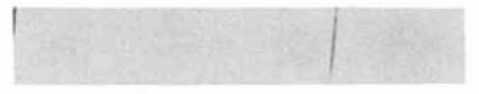

\section{Fat}

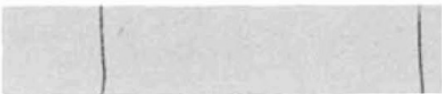

\section{Yeast tRNA}

as described in Materials and Methods. No nonspecific hybridization signal is evident in fat total RNA or yeast tRNA dots.
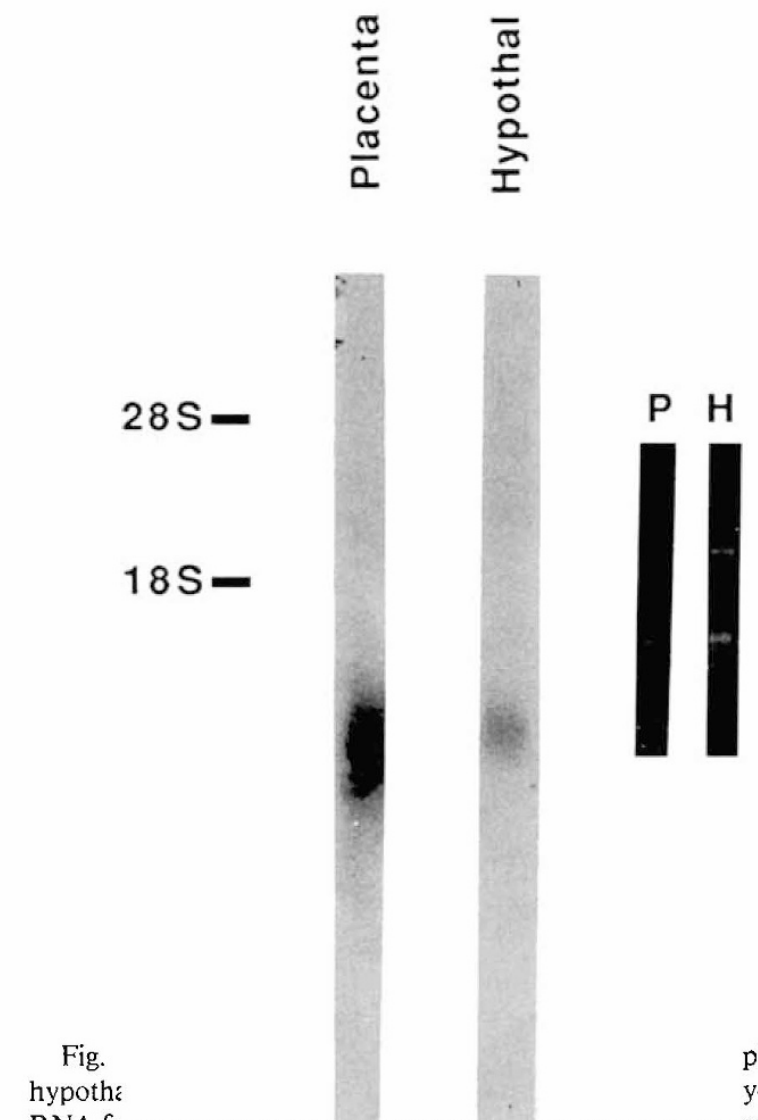

placenta and $y$-A enriched RNA frun pracenta anu ny pundranus were suvjeuteu tu enectrophoresis in each lane. Size markers are $18 \mathrm{~S}$ and $28 \mathrm{~S}$ ribosomal RNA. Migration of the placental band is slightly farther than that seen in hypothalamus. Inset shows the gel lanes from which these blots were transferred. Intensities of residual ribosomal RNA bands in each lane were approximately equal. The lane designated $P$ contains placental poly-A enriched RNA and lane $H$ contains hypothalamic poly-A enriched RNA.

and/or more abundant than in hypothalamus. No signal was seen in similar amounts of total RNA from white fat, or when yeast tRNA was applied, suggesting that the signal generated is specific to GHRH. On Northern analysis of poly-A enriched RNA, placental rat GHRH mRNA was $\sim 700$ nucleotides in length (Fig. 2), and the band of hybridization migrated slightly farther than the signal observed in hypothalamus. The magnitude of difference is difficult to assess because the only basis for comparison is the much larger $18 \mathrm{~S}$ and $28 \mathrm{~S}$ ribosomal RNA species, but it averaged $\sim 50$ to 100 nucleotides.

To assess the degree of homology between placental hypothalamic GHRH mRNA, we used the hypothalamic cDNA to perform an RNAse protection assay of placental total RNA. In vitro generated hypothalamic GHRH sense-cRNA and placental total RNA were hybridized in solution to labeled antisense GHRHcRNA. The fragment protected by the full-length, in vitro generated hypothalamic cRNA is identical in size to that seen in placental total RNA after digestion with RNAses A and T1 (Fig. 3 ). No hybridization signal is seen when yeast tRNA is used instead of placental RNA.

Ontogeny of GHRH $m R N A$ in placenta. To determine the ontogeny of GHRH in placenta, placentas were harvested from timed-pregnant females at varying times of gestation. GHRH mRNA in placenta measured by dot-blot hybridization was detectable $(0.18 \pm 0.04 \mathrm{pg}$ GHRH $\mathrm{cRNA} / \mu \mathrm{g}$ placental total RNA) ( $n=4$ at all time points) at the earliest date examined (d $7)$, but increased more than 2 -fold $(0.46 \pm 0.13 \mathrm{pg} / \mu \mathrm{g}$ total RNA) at $\mathrm{d} 14$ and 5 -fold by d $17(1.31 \pm 0.14 \mathrm{pg} / \mu \mathrm{g}$ total RNA). Quantities were unchanged at d 20 of gestation (Fig. $4 A$ and $B$ ). On a Northern blot of total RNA (Fig. 4C), a hybridization signal was apparent by $\mathrm{d} 14$ and increased in a fashion similar to that noted in the dot blots. Only one major RNA species was seen on $\mathrm{d} 14$ and 17 ( $\sim 25$ nucleotides); however, in d 20 placenta, two additional species were apparent, one slightly smaller ( $\sim 700$ nucleotides) and one larger ( $\sim 3550$ nucleotides).

Ontogeny of IGF-I and IGF-II mRNA in placenta. Dot blot and Northern hybridizations of IGF-I and IGF-II mRNA were also performed to compare the ontogeny of these placentally expressed growth factors with placental GHRH. In contrast to GHRH, IGF-I mRNA in placenta was highest at d 10 of gestation $(19.67 \pm 2.67 \mathrm{pg}$ IGF-I mRNA/ $\mu \mathrm{g}$ total RNA) and decreased by d 14 to levels below the detection limit (Fig. 5), whereas IGF-II mRNA was not seen in d 7 and 10 samples, but was readily detected at $\mathrm{d} 14,17$, and 20 of gestation $(323.9 \pm 26.7,417.7 \pm$ 2.76 , and $411 \pm 40.6 \mathrm{pg} \mathrm{IGF-II} \mathrm{mRNA/ \mu g}$ total RNA, respectively) (Fig. 6). On Northern blots, IGF-I mRNA was faintly present at $\mathrm{d} 7$ of gestation and visible only on prolonged exposures (data not shown). The pattern of RNA species seen was identical to that seen at $\mathrm{d} 10$. The predominant IGF-II mRNA

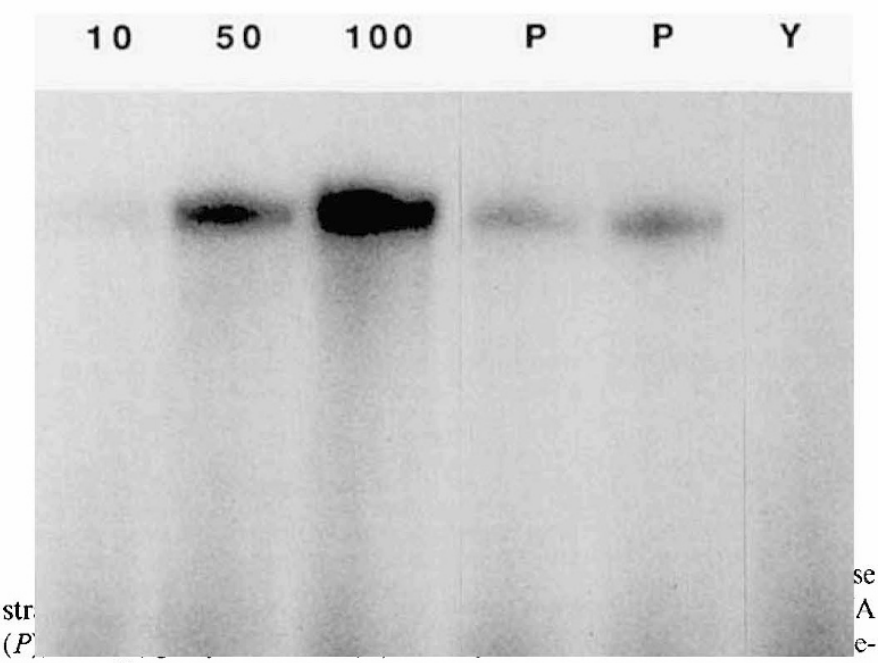

GHRH [ $\left.{ }^{32} \mathrm{P}\right]$-labeled cRNA, followed by RNAse A and Tl digestion. After PAGE, the dried gel was radiographed for $24 \mathrm{~h}$. A protected fragment in placenta is identical in size to that protected by hybridization of sense and antisense strands of full-length hypothalamic GHRH cRNA. 


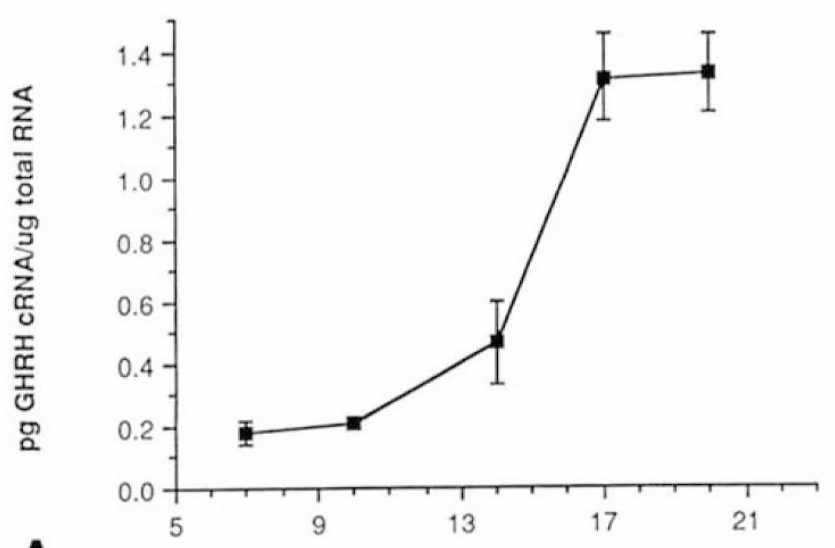

A

Days of Gestation $\begin{array}{lllll}7 & 10 & 14 & 17 & 20\end{array}$
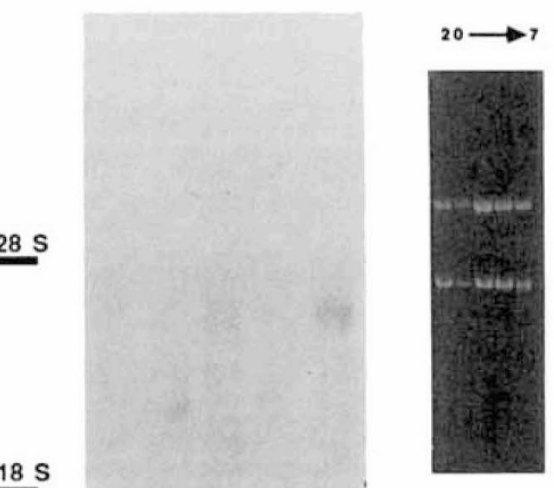

$7 d$

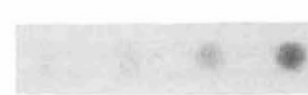

$10 \mathrm{~d}$

$14 d$

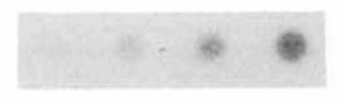

$17 d$

$20 d$
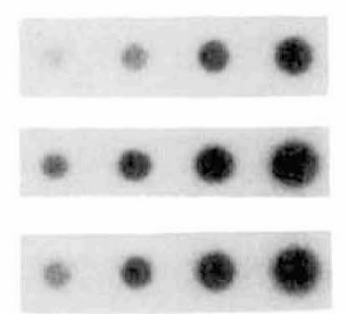

$\mu \mathrm{g}$
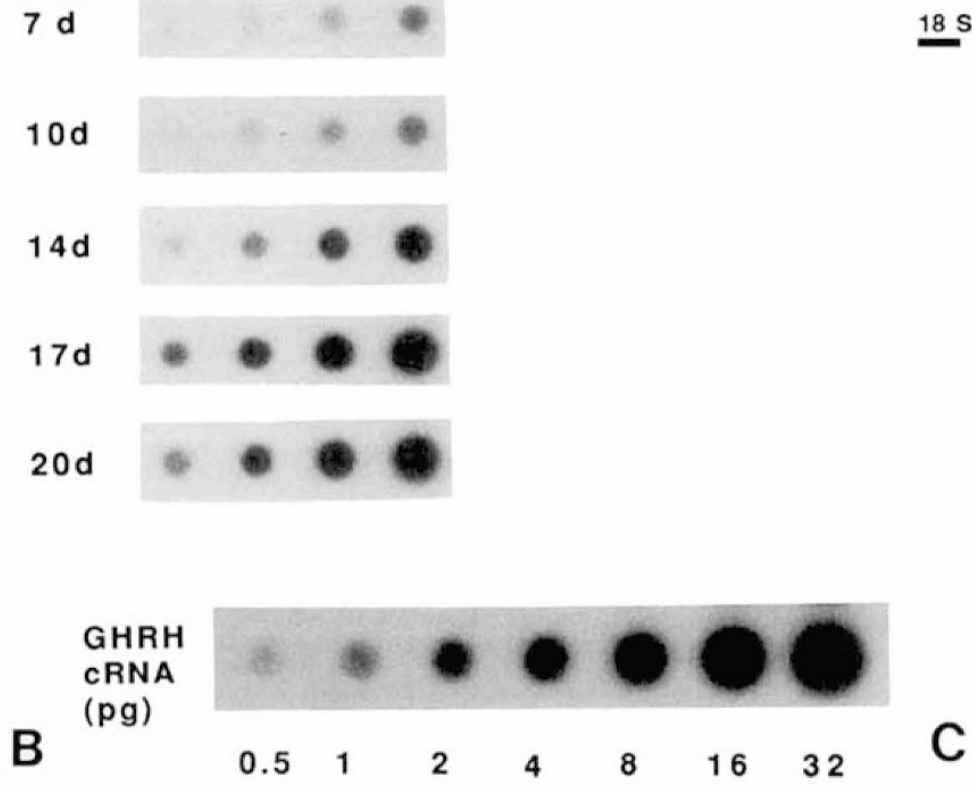

C

Fig. 4. Ontogeny of GHRH mRNA in placenta. Panel A, amounts of GHRH cRNA per $\mu \mathrm{g}$ placental total RNA at varying ages. Shown are mean values \pm SEM, $n=4$ in each group. Panel $B$, representative dot-blot hybridization signal for each age (upper) and GHRH cRNA standard (lower). Panel C, Northern gel of representative sample at each gestational age (shown on top). Size markers are 18S and 28S RNA. Inset shows ethidium bromide staining of the Northern gel (lanes are reversed, as noted above the inset). Intensity of the d 17 RNA is slightly less than that for other days due to a pipetting error. Ten $\mu \mathrm{g}$ was applied to each lane.

band was at $4.0 \mathrm{~kb}$, with additional faint bands visualized on prolonged exposures.

\section{DISCUSSION}

Previous reports have documented the presence of immunoreactive $(5,6)$ and biologically active GHRH in rat placenta $(5)$. In the most recent of these reports, GHRH concentrations in placenta did not change from d 13 through term, although GHRH content did increase from d 13 to d 20 of gestation. Although some substances such as large polypeptides seem to be excluded from transfer across the placenta, flux of other substances across placental tissue can occur by a number of mechanisms: I) simple diffusion (i.e. anesthetic gases), 2) restricted diffusion (i.e. hydrophilic substances), 3) facilitated diffusion (i.e. glucose), 4) active transport (amino acids), and 5) receptormediated endocytosis $(\mathrm{IgG})(22)$. Thus, the finding of GHRH in placental extracts is not proof of placental origin.

The finding of a GHRH mRNA sequence in placenta that hybridizes to GHRH cRNA under stringent conditions lends

strong support to its placental origin. The GHRH mRNA present in placenta is similar in character to that produced in the hypothalamus, as determined by the presence of a protected fragment of identical size after RNAse digestion using a hypothalamic GHRH cRNA in the protection assay. However, at d 20 we noted three apparent RNA species. One band is of the size of hypothalamic GHRH mRNA and is present in all lanes of the Northern blot. Although the smaller species may be artifactual, we have observed a broad band at $\mathrm{d} 20$ of gestation in all previous gels, including in our poly-A hybridization. The larger band was also not seen previously in examination of rat placental RNA (7), and is not evident in our sample of poly-A enriched placental RNA. It is larger than the major GHRH-like RNA in testis, but is the same size as a lighter band seen in testis at postnatal $\mathrm{d} 65$ and 90 (23). The significance of the alternate species is not known. The larger RNA could be a precursor, or the differences in the bands could be secondary to alternative splicing or processing. Whether the alternate bands are of physiologic significance and are differentially regulated is still unknown. 


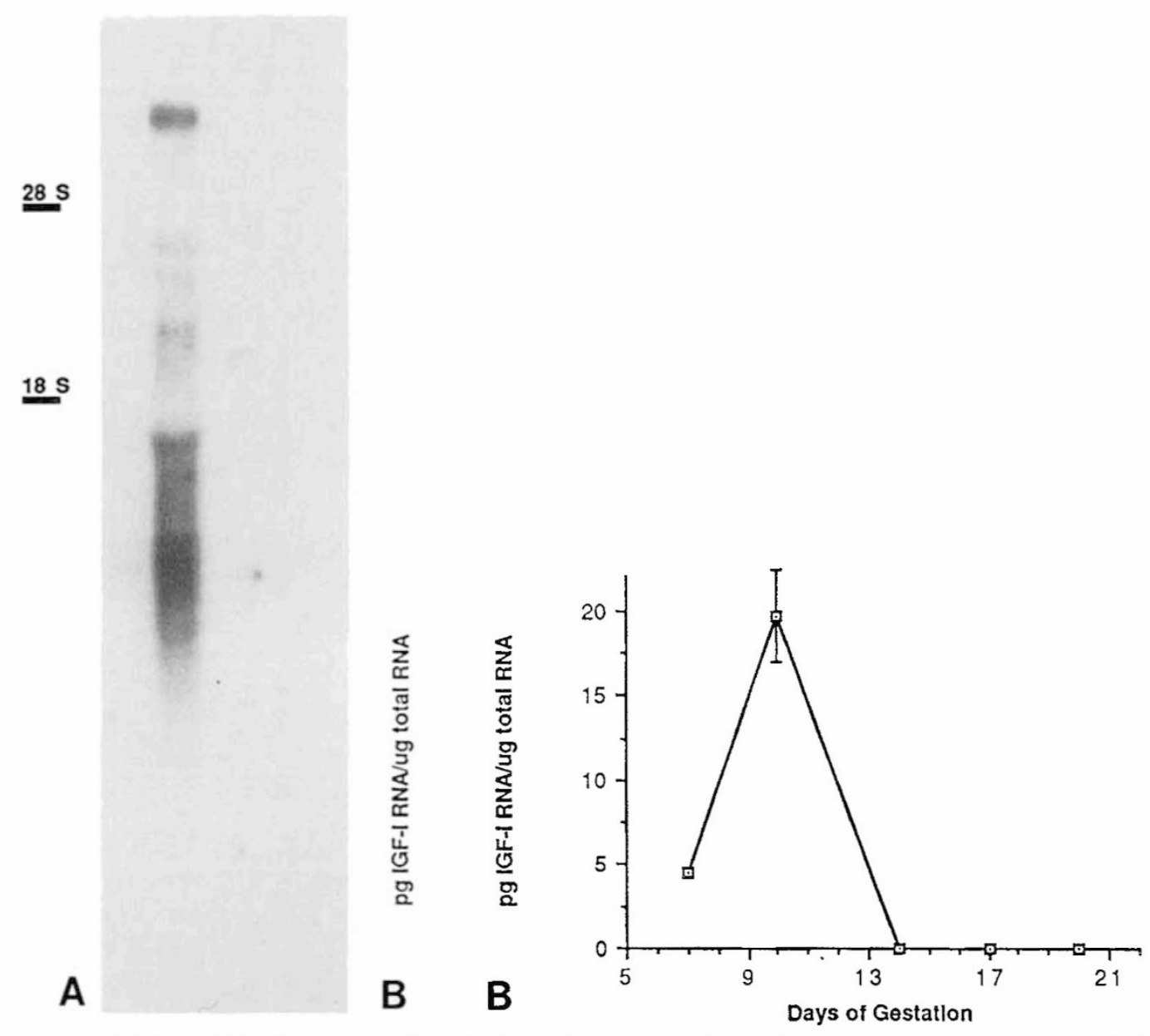

Fig. 5. Ontogeny of IGF-I mRNA in placenta. The Northern blot used in Figure $4 C$ was stripped and reprobed with IGF-I cDNA $(A)$. Size markers are $18 \mathrm{~S}$ and $28 \mathrm{~S}$ ribosomal RNA. Four individual placentas at each time point were examined by dot blot for quantitation of the changes in all IGF-I mRNA species, and compared to fixed quantities of an in vitro-generated sense strand IGF-I cRNA $(B)$. Values shown are means \pm SEM.

Three other groups have also documented the presence of GHRH mRNA in placenta $(8,9,24)$. Suhr et al. (8) cloned and sequenced GHRH in mouse using a d 13 gestation placental cDNA library. They found that GHRH mRNA is present at $d$ 14 of mouse gestation and increases in the latter half of gestation, much as we observed in rat. The band of hybridization for the major RNA species in placenta in their Northern gel is also broader, and possibly smaller, than the hypothalamic signal. A larger species is also present on their Northern blot. Using in situ hybridization, they showed that GHRH is expressed in trophoblast giant cells. Miargioris et al. (9) made the same observation in rat placenta, and also saw a strong placental signal in a Northern blot of total RNA. They found that secretion of placental GHRH seemed to be regulated by both adenyl cyclase and protein kinase $C$ pathways (9). These studies strongly support the hypothesis of local production of GHRH by the placenta.

Like other hypothalamic-like peptides found in placenta, the function of GHRH in placenta is unknown. Placental releasing hormones may regulate placental pituitary-like hormones, as has been suggested for both placental corticotrophin releasing hormone and gonadotropin releasing hormone $(2,4,25,26)$. Similarly, the placenta could have a growth axis analogous to the hypothalamic-pituitary-target tissue axis. The placenta expresses all the components of such an axis, including GHRH, GH-like hormones, and IGF.

A number of $\mathrm{GH}$ gene family members are expressed in rat placenta, including PLP-A, PLP-B, PL-I, and PL-II. The physi- ologic role of these GH-like peptides remains unknown, although they have distinctive ontogenetic changes during gestation. There is a rapid increase in PL-I during midgestation (d 10-13), followed by a fall in peptide levels (27). PL-II, PLP-A, and PLP-B mRNA increase significantly beginning at $\mathrm{d} 12,14$, and 15 and are expressed until term (28-30), not unlike our observation of placental GHRH mRNA.

The physiologic significance of the GH-like peptides in placenta is unknown. PL has been proposed as the fetal GH by many investigators, but the evidence supporting this hypothesis is still controversial. Although production of $\mathrm{PL}$ is massive, appears early in human pregnancy, and increases in parallel with placental weight, its absence in humans does not seem to be detrimental to growth. Infants with complete deletions of the PL genes have normal prenatal growth, despite extremely low levels of this hormone in the maternal circulation (31,32). Although it has both lactogenic and somatogenic properties (33), it is not potent as a postnatal GH (34). Although PL may not be essential in human fetal growth, much of the existing evidence suggests that it is more important in the fetal rat. In rats, it is an anabolic hormone that promotes amino acid transport into tissues, as $\mathrm{GH}$ does in postnatal life (35). PL can stimulate IGF-I production (36-38) and is detectable in fetal serum, and there are unique high-affinity PL receptors in fetal tissues (39).Furthermore, in the rat, administration of human PL by implantable minipump during late gestation results in accelerated fetal weight gain (40), and reverses the effects of low-protein diet on fetal somatomedin levels (41). 

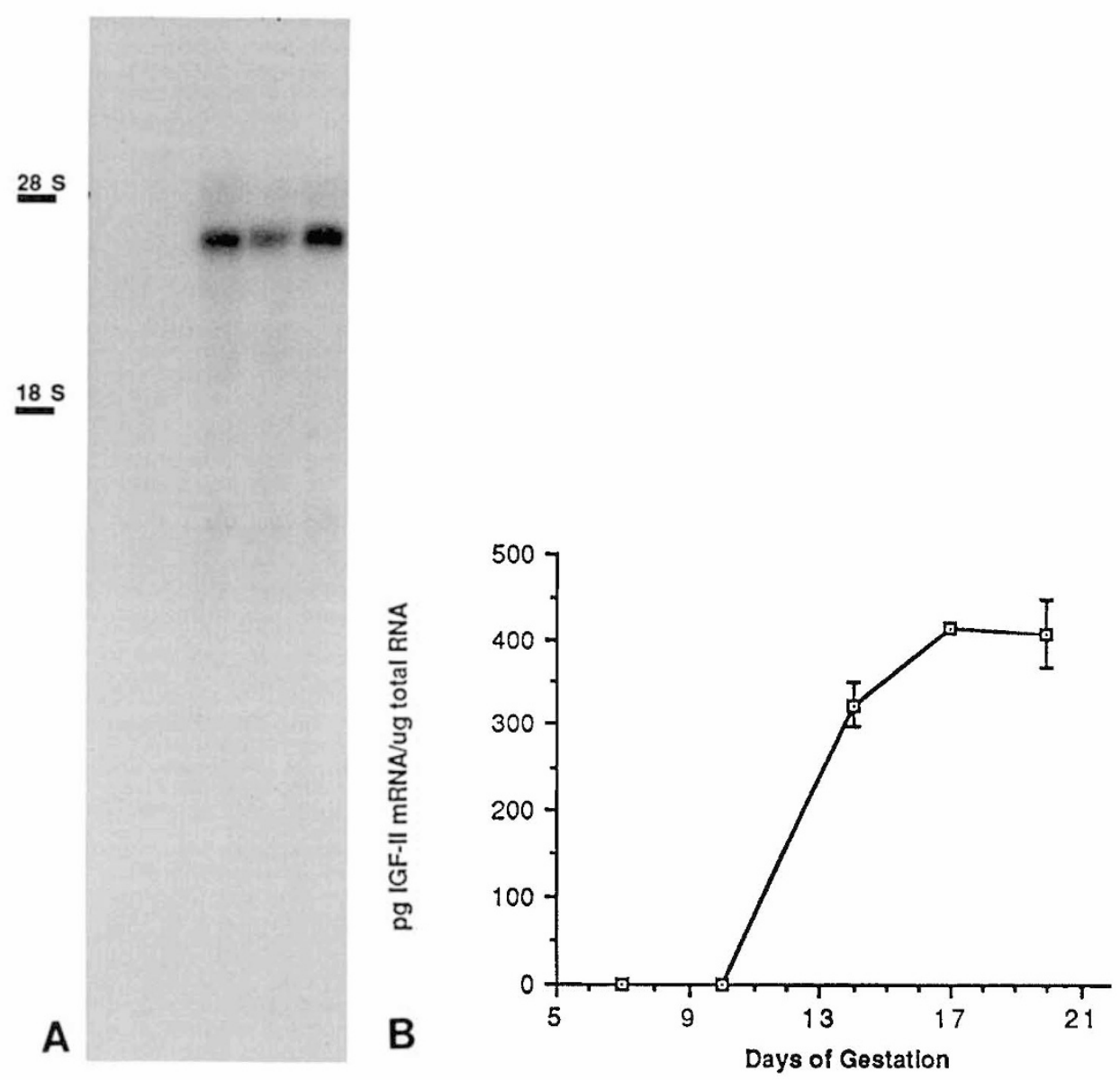

Fig. 6. Ontogeny of IGF-II mRNA in placenta. The Northern blot in Figures 4 and 5 was reprobed with IGF-II cDNA $(A)$, and the individual placental samples (four per time point) were evaluated by dot blot. Size markers are $18 \mathrm{~S}$ and $28 \mathrm{~S}$ ribosomal RNA. The individual data points were compared to fixed quantities of an in vitro-generated sense strand IGF-II cRNA $(B)$. Values shown are means \pm SEM.

Both IGF-I and IGF-II have been found in human placenta, where IGF-I mRNA is higher in 1 st and 2nd trimester placentas than in term placentas (42). Changes in IGF-I in developing rat placenta have not been examined. Shen et al. (43) found that IGF-II mRNA in human placenta was highest in the 2nd trimester (43). In rodents, an IGF-II cDNA was found in a mouse d 19 placental library (44), and term rat placentas express IGF-II mRNA (45), but no studies have examined the ontogeny of placental IGF-II. Most investigators believe that the contribution of IGF-I to fetal growth is limited in comparison to other growth factors. This conclusion is based on the finding that fetal serum IGF-I and hepatic IGF-I mRNA levels are considerably lower than in normal adult animals (46). In contrast, IGF-II is relatively abundant in fetal life in comparison to its postnatal levels (47, 48 ), and is not significantly influenced by GH (38). For these reasons, it has been proposed that IGF-II could be the primary fetal somatomedin (38). Both IGF are induced by PL in specific tissues: PL induces IGF-I expression in cultured human fetal pancreas (36) and induces IGF-II in rat fetal fibroblasts (38).

In this study, we demonstrated that the expression of IGF-I mRNA in rat placenta is highest in midgestation around $\mathrm{d} 10$, essentially concomitant with published reports of peak expression of PL-I, and before increases in embryonic IGF-I expression (49). The RNA pattern seen is like that previously described in liver (50). Although we were not able to completely separate fetal tissues from 7 and 10 placental samples, the low levels of IGFI expression in d 11 embryos seen by Rotwein et al. (49) suggest that the peak in IGF-I expression seen in our samples is probably due to placental expression of IGF-I. IGF-II mRNA expression in placenta is not detected at $\mathrm{d} 7$ and 10 and is maximal by $\mathrm{d}$ 14. The predominant IGF-II mRNA band was at $4.0 \mathrm{~kb}$, with additional faint bands visualized on prolonged exposures, as described by others $(45,50)$. Inasmuch as we did not examine d 11-13 placentas, we cannot precisely time the day at which IGFII mRNA expression begins to increase. Rotwein et al. (49) further found that IGF-II was readily demonstrable in d 11 rat embryonic tissue, whereas even on prolonged exposures of IGFII dot blots, no apparent expression was seen in $\mathrm{d} 10$ placenta. Unless a marked increase in placental IGF-II expression occurs on 11 , our observations suggest that the regulation of expression of IGF in placenta and embryo is temporally discordant.

The interaction of placental hormones is likely to be complex and to result in a changing hormonal environment for both mother and fetus. If placental GHRH serves as a regulator of placental GH-like hormones, it is likely to do so only in the latter half of gestation. By temporal association, the most likely $\mathrm{GH}$-like targets for placental GHRH action in the rat might be PL-II, PLP-A, or PLP-B. Our data are consistent with, although not proof of, placental GHRH having an interactive role with placental IGF-II during the last week of rat gestation. They do not support a role for placental GHRH in placental IGF-I regulation. Further examination of the regulation of placental GHRH should provide insight about the function of placental hormones.

Acknowledgments. The authors thank Mary Bundy, Pearl Bergad, and Ann Margaret Myers for their excellent technical assistance. 


\section{REFERENCES}

1. Sasaki A, Shinkawa O, Margioris AN, Liotta AS, Sato S, Murakami O, Go M, Shimizu Y, Hanew K, Yoshinaga K 1987 Immunoreactive corticotropinreleasing hormone in human plasma during pregnancy, labor, and delivery. J Clin Endocrinol Metab 64:224-229

2. Khodr GS, Siler-Khodr TM 1980 Placental luteinizing hormone-releasing factor and its synthesis. Science 207:315-317

3. Gibbons JM, Mitnick M, Chieffo V 1975 In vitro biosynthesis of TSH and LH-releasing factors by the placenta. Am J Obstet Gynecol 121:127-13

4. Margioris AN, Grino M, Protos P, Gold PW, Chrousos GP 1988 Corticotropin releasing hormone and oxytocin stimulate the release of placental proopiomelanocortin peptides. J Clin Endocrinol Metab 66:922-926

5. Baird A, Wehrenberg WB, Bohlen $P$, Ling N 1985 Immunoreactive and biologically active growth hormone-releasing factor in the rat placenta. Endocrinology 117:1598-1601

6. Meigan G, Sasaki A, Yoshinaga K 1988 Immunoreactive growth hormonereleasing hormone in rat placenta. Endocrinology 123:1098 1102

7. Pescovitz OH, Wehrenberg W, Gelato MC, Healy D, Bundy M, Seelig S, Berry SA 1988 Growth hormone releasing hormone in placenta and its possible role in fetal growth. 70th Annual Endocrine Society Meeting, abstract no. 263 , p 86

8. Suhr ST, Rahal JO, Mayo KE 1989 Mouse growth hormone-releasing hormone: precursor structure and expression in brain and placenta. Mol Endocrinol 3:1693-1700

9. Margioris AN, Brockmann G, Bohler HCL, Grino M, Vamvakopoulos N, Chrousos GP 1990 Expression and localization of growth hormone-releasing hormone messenger ribonucleic acid in rat placenta: in vitro secretion and regulation of its peptide product. Endocrinology 126:151-158

10. Pescovitz OH, Berry SA, Laudon M, Ben-Jonathan N, Martin-Meyers A, Hsu S-M, Lambros TJ, Felix AM 1990 Localization and growth hormone releasing activity of rat testis growth hormone releasing hormone-like peptide. Endocrinology 127:2336-2342

11. Pescovitz OH, Gelato MC, Bundy M, Loriaux DL, Merriam GR, Pescovitz MD 1986 Production of monoclonal antibodies against human growth hormone releasing hormone and their use in an enzyme-linked immunosorbent assay (ELISA). $J$ Immunol Methods 94:257-262

12. Berry SA, Pescovitz OH 1988 Identification of a GHRH-like substance and its messenger RNA in rat testis. Endocrinology 123:661-663

13. Jansson JO, Ishikawa K, Katakami H, Frohman L 1987 Pre- and postnatal developmental changes in hypothalamic content of rat growth hormone releasing factor. Endocrinology 120:525-530

14. Berry SA, Seelig S 1986 Differential regulation of alpha-2 $2_{u}$-globulin gene products. Endocrinology 119:600-605

15. Descos BP, Berry SA, Weisdorf SA, Gross CP, Sharp HL, Pescovitz OH 1989 The effect of nutritional intake on IGF-I levels and growth failure in cholestatic rats. Pediatr Res 26:410-414

16. Whitfield HJ, Bruni CB, Frunzio R Terrell JE, Nissley SP, Rechler MM 1984 Isolation of a cDNA clone encoding rat insulin-like growth factor II precursor. Nature 312:277-280

17. Melton DA, Krieg PA, Rebagliati MR, Maniatis T, Zinn K, Green MR 1984 Efficient in vitro synthesis of biologically active RNA and RNA hybridization probes for plasmids containing a bacteriophage SP6 promotor. Nucleic Acids Res 12;7035-7056

18. Feinberg AP, Vogelstein B 1983 A technique for radiolabeling DNA restriction fragments to high specific activity. Anal Biochem 132:6-13

19. Feinberg AP, Vogelstein B 1984 Addendum. Anal Biochem 137:266-267

20. Durham DM, Palmiter RD 1983 A practical approach to quantitating specific mRNAs by solution hybridization. Anal Biochem 131:385-393

21. Mariash CN, Seelig S, Oppenheimer JM 1982 A rapid, inexpensive, quantitative technique for the analysis of two-dimensional electrophoretograms. Anal Biochem 121:388-394

22. Boyd RDH 1988 Placental transport. In: Knobil E, Neill J (eds) The Physiology of Reproduction. Raven Press, New York, pp 2043-2083

23. Berry S, Pescovitz OH 1990 The ontogeny of testicular growth hormone releasing hormone-like messenger RNA. Endocrinology 127:1404-1411

24. Frohman MA, Downs TR, Chomczynski P, Frohman LA 1989 Cloning and characterization of mouse growth hormone-releasing hormone (GRH) complementary DNA: increased GRH Messenger RNA levels in the growth hormone deficient lit/lit mouse. Mol Endocrinol 3:1529-1536

25. Petraglia F, Sawchenko PE, Rivier J, Vale W 1987 Evidence for local stimulation of ACTH secretion by corticotropin-releasing factor in human placenta. Nature 328:717-719
26. Siler-Khodr TM, Khodr GS 1981 Dose response analysis of GnRH stimulation of hCG release from human term placenta. Biol Reprod 25:353-358

27. Robertson MC, Gillespie B, Friesen HG 1982 Characterization of the two forms of rat placental lactogen (rPL): rPL-I and rPL-II. Endocrinology $111: 1862-1873$

28. Duckworth ML, Kirk KL, Friesen HG 1986 Isolation of a cDNA clone of rat placental lactogen II. J Biol Chem 261:10871-10878

29. Duckworth ML Peden LM, Friesen HG 1986 Isolation of a novel prolactinlike cDNA clone from developing rat placenta. J Biol Chem 261:10879_ 10884

30. Duckworth ML, Peden LM, Friesen HG 1988 A third prolactin-like protein expressed by the developing rat placenta complementary deoxyribonucleic acid sequences and partial structure of the gene. Mol Endocrinology 2:912920

31. Simon PH, Decoster C, Brocas H, Schwers J, Vassart G 1986 Absence of human chorionic somatomammotropin during pregnancy associated with two types of gene deletion. Hum Genet 74:235-238

32. Wurzel JM, Parks JS, Herd JE, Nielsen PV 1982 A gene deletion is responsible for absence of human chorionic somatomammotropin. DNA 1:251-257

33. Buster JE, Simon JA 1989 Placental hormones, hormonal preparation for and control of parturition, and hormonal diagnosis of pregnancy. In: DeGroot LJ (ed) Endocrinology, Vol 3. WB Saunders, Philadelphia, pp 2051-2069

34. Grumbach MM, Kaplan SL 1971 Clinical investigation. In: Peelie A, Müller EE (eds) Second International Symposium on Growth Hormone. Excerpta Medica, Amsterdam, pp 382-389

35. Freemark M, Handwerger S 1983 Ovine placental lactogen stimulates amino acid transport in fetal rat diaphragm. Endocrinology 112:402-404

36. Swenne I, Hill DJ, Strain AJ, Milner RD 1987 Effects of human placental lactogen and growth hormone on the production of insulin and somatomedin $\mathrm{C} /$ insulin-like growth factor 1 by human fetal pancreas in tissue culture. $\mathbf{J}$ Endocrinol 113:297-303

37. Hurley TW, D'Ercole AI, Handwerger S, Underwood LE, Furlanetto RW, Fellows RE 1977 Ovine placental lactogen induces somatomedin: a possible role in fetal growth. Endocrinology 101:1635-1642

38. Adams SO, Nissley SP, Handwerger S, Rechler MM 1983 Developmental patterns of insulin-like growth factor- 1 and 2 synthesis and regulation in rat fibroblasts. Nature 302:150-152

39. Freemark M, Comer M, Korner G, Handwerger S 1987 A unique placental lactogen receptor: implications for fetal growth. Endocrinology 120:18651872

40. Collins JW, Finley SL, Merrick D, Ogata ES 1988 Human placental lactogen administration in the pregnant rat: acceleration of fetal growth. Pediatr Res 24:663-667

41. Pilistine SJ, Moses AC, Munro HN 1984 Placental lactogen administration reverses the effect of low-protein diet on maternal and fetal serum somatomedin levels in the pregnant rat. Proc Natl Acad Sci USA 81:5853-5857

42. Wang C-Y, Daimon M, Shen S-J, Engelmann GL, Ilan J 1988 Insulin-like growth factor-I messenger ribonucleic acid in the developing human placenta and in term placenta of diabetics. Mol Endocrinol 2:217-229

43. Shen SJ, Wang CY, Nelson KK, Jansen M, llan J 1986 Expression of insulinlike growth factor II in human placentas from normal and diabetic pregnancies. Proc Natl Acad Sci USA 83:9179-9182

44. Stempien MM, Fong NM, Rall LB, Bell GI 1986 Sequence of a placental cDNA encoding the mouse insulin-like growth factor II precursor. DNA $5: 357-361$

45. Romanus JA, Yang YW-H, Adams SO, Sofair AN, Tseng LY-H, Nissley SP Rechler MM 1988 Synthesis of insulin-like growth factor II (IGF-II) in fetal rat tissues: translation of IGF-II ribonucleic acid and processing of pre-pro IGF-II. Endocrinology 122:709-716

46. Han VKM, Lund PK, Lee DC, D'Ercole AJ 1988 Expression of somatomedin/ insulin-like growth factor messenger ribonucleic acids in the human fetus: identification, characterization, and tissue distribution. J Clin Endocrinol Metab 66:422-429

47. Foley TP, DePhillip R, Perricelli A, Miller A 1980 Low somatomedin activity in cord serum from infants with intrauterine growth retardation. J Pediatr 96:605-610

48. Milner RDG, Hill DJ 1984 Fetal growth control: the role of insulin and related peptides. Clin Endocrinol (Oxf) 21:415-433

49. Rotwein P, Pollack KM, Watson M, Milbrandt JD 1987 Insulin-like growth factor gene expression in rat embryogenesis. Endocrinology 121:2141-2144

50. Roberts CT, Brown AL, Graham DE, Seelig S, Berry S, Gabbay KH, Rechler MM 1986 Growth hormone regulates the abundance of insulin-like growth factor I RNA in adult rat liver. J Biol Chem 261:10025-10028 